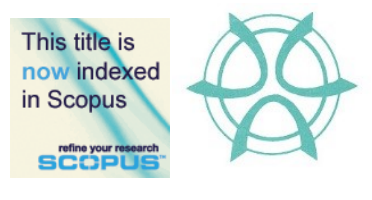

PLANNING MALAYSIA:

Journal of the Malaysian Institute of Planners

VOLUME 18 ISSUE 2 (2020), Page 12 - 23

\title{
HERITAGE IDENTITY CONSERVATION OF THE WOODCARVING PLACEMENT AND DESIGN COMPOSITION TYPOLOGIES ON JOHOR MALAY HOUSES
}

\author{
Hanita Yusof ${ }^{1}$, Fawazul Khair Ibrahim ${ }^{2}$ \& Raja Nafida Raja Shahminan ${ }^{3}$ \\ ${ }^{I}$ Faculty of Civil Engineering and Built Environment \\ UNIVERSITI TUN HUSSEIN ONN MALAYSIA \\ ${ }^{2,3}$ Faculty of Built Environment \& Surveying \\ UNIVERSITI TEKNOLOGI MALAYSIA
}

\begin{abstract}
Woodcarving is a distinct heritage that can promote the identity of a region. However, current practices of using the design composition and woodcarving placement which do not belong to the local region pose a threat to the identity and authenticity of the original heritage. If such practices continue and the identity of the local heritage is not preserved and recorded, the traditional designs and local identity will eventually be lost. The objective of this paper is to identify the placements of woodcarving and the typology of design compositions of woodcarving which form the identity of the Johor Malay houses. Site visits were conducted to Limas Johor in which the wood carvings of 50 houses were examined, photographed and documented. Interviews were also conducted with the house owners or occupants, and the wood carvers. The samples were analyzed and the results were verified by experts. A total of 10 woodcarving placements and 23 typologies were discovered, drawn and coded. The findings of this research suggest that the typology combination of JT2-P5+KT7 of woodcarving represents the identity of Limas Johor houses. It is hoped that this study can bring recognition to Johor woodcarvings, contribute valuable guides for woodcarvers to apply these typologies into their future works to sustain and cherish the Johor local identity.
\end{abstract}

Keywords: Wood Carving, Malay Woodcarving, Malay Woodcarving Motif, Limas Johor, Traditional House, Vernacular Architecture.

${ }^{1}$ Senior Lecturer at Universiti Tun Hussein Onn Malaysia. Email: itastopa74@gmail.com 
PLANNING MALAYSIA

Journal of the Malaysia Institute of Planners (2020)

\section{INTRODUCTION}

Malaysia is well-known for her cultural diversity and rich with traditional heritage. Malay is one of the major ethnic groups in Malaysia and is considered as the majority of the country's population which contributes to the significant heritage including art, decoration and even architecture. Traditional woodcarving is an intricate Malay heritage and is the symbol of Malay art. This traditional heritage of woodcarving should be loved, preserved, treasured and passed along from generation to generation (Silah et al., 2013). Woodcarving was created and designed to provide convenience and enhance the art of Malay culture (Jenkins, 2010). The decorated structural design in woodcarving serves as a symbol of high social status in the Malay community (Norhaiza Noordin, 2009). Apart from the status factor, the love and appreciation towards its beauty also has caused woodcarving developed from the nobility to ordinary people (Zulkifli Hanafi, $2007 ; 2015)$ and became quite an important element in traditional Malay houses. Despite being an important element, woodcarving is on the brink of being disregarded due to the current practices of selecting design composition and woodcarving placement which do not belong to the local region. These practices pose a threat to the local identity and authenticity of the local heritage. If such practices continue and the identity of the local heritage is not identified and recorded, the traditional designs and local identity left by the local ancestors will eventually be lost. The deficiency of dissertation, research studies and documentation relating to the Malaysian architectural identity is one of the factors that contribute to an ongoing misinterpretation on the idea of finding the architectural identity (Nor Hayati, 2015). Due to that, the objective of this paper is to identify the placements of woodcarving and the typologies of design compositions of woodcarving in order to form the identity of the Johor traditional Malay houses.

\section{RESEARCH BACKGROUND}

Traditional Malay houses are commonly decorated with woodcarvings that have beautiful motifs, placements and design composition. These woodcarvings represent the Malay culture and should be perceived, appreciated and preserved. However, vast urbanisation has actually created such a huge impact where the old houses were being renovated using modern elements and components due to the rapid development of architectural style and recent technology (Mohamad Tajuddin, 2006; Zumahiran \& Ismail, 2010). Hence, it is important to conduct a research on woodcarvings found in the traditional Malay houses. Studies have been carried out in the vicinity of Kelantan, Terengganu, Kedah, Perak, Negeri Sembilan and Melaka to examine on their local woodcarving. This research examined woodcarvings on traditional Malay houses in Johor. 
Hanita Yusof, Fawazul Khair Ibrahim, Raja Nafida Raja Shahminan

Heritage Identity Conservation of The Woodcarving Placement and Design Composition Typologies on Johor Malay Houses

One of the biggest issues that create a challenge in preserving this Malay heritage in Johor is about the abandonment of traditional houses that comes with woodcarving. It is such a waste to see our heritage of woodcarving being destroyed unappreciated and undocumented. More and more traditional Malay houses are being demolished day by day. Yilmaz \& Maz (2006) stated that in this era, many cultures and heritages are threatened for extinction, lost and destroyed from the memory even the memory of the family members who moved to pursue with the current trend and modernity. Those typologies that haven't been recorded will be gone and forgotten. The Kongres Budaya 2017 has raised up the problem regarding the destruction of cultural heritage on traditional buildings that leads to losing of identity. Mastor Surat (2012) and Kamarul Afizi Kosman (2012) have emphasised that it is important for every state to participate in the effort of preserving its own architectural heritage in line with the government's goals.

Another biggest issue is regarding the identity crisis. This issue arises when creating identity without studying on the local cultural heritage and is solely top down, created by top management or by copying what is existed in other country. Identity based on replicative copy of foreign elements is unacceptable due to the fact that it is not complimenting true to history and not referring to local design values, and as being foreign to Johor. The definition of the Johor's cultural heritage is seen as the responsibility of the highest leader in the state, which are not always looking directly on the place or its genius loci (Gurupiah \& Syed Iskandar, 2016). The malfunction integrity of an architect was highlighted with a commercialism approach and the mind bondage towards top down views (Mohamad Tajuddin \& Kamarul Afizi, 2005). Conflicts of identity also arise when new generations of local carvers in Johor adopted woodcarving placements and design composition typologies from other states such as Kelantan and Terengganu, as well as from foreign countries such as Bali, Myanmar and India. Strong influences of non-local features are feared to dominate and overshadow our own heritage (Norhaiza Noordin, 2017). Most carvers including the Johor local carvers learnt carving from the East Coasts and Indonesia, and some may used Bali motifs in their carvings which, unfortunately, do not reflect the local identity (Abu Bakar Yatim, 2015). This issue on identity crisis occurred because through interviews, it was found that Johor woodcarvers Johor woodcarvers has not made any detailed study related to woodcarving placements and design composition typologies on Johor traditional houses that have existed for more than 100 years.

\section{METHODOLOGY}

The research employed a case study design and the data collection methods involved field study and interviews. The research started with obtaining information about the traditional Malay houses that can be found throughout 
Johor. Site visits and inventory were conducted to 110 traditional Malay Johor houses and from there, 50 houses that falls under the category of Limas Johor were then selected for the case study in which the houses and woodcarvings were examined, observed, photographed and documented. Other categories are under Rumah Bumbung Panjang and Rumah Perabung Lima while Rumah Bumbung Limas were chosen because this category falls under Johor identity.

These 50 houses of Limas Johor were chosen based on their age, distinctive woodcarvings and significant huge placements. The houses were built as early as 1820 . The house residents were interviewed to obtain information related to the year the house and the woodcarvings were built, the influences and functions apart from the details of the house owner, address and captured ample related photographs. Interviews and analytic reviews were also conducted with professionals consisting of four local woodcarvers and woodcarving experts around Johor. Data gathered from the site visits were then analysed with narration and interpretation from these prominent local woodcarvers. The data collected and woodcarving samples were analysed and discussed with experts for verification. Apart from the Johor local woodcarvers, the interview was also done with Malaysia's leading woodcarver, Norhaiza Noordin, who is the Yang Dipertua Persatuan Penggiat Seni Ukir Kayu Malaysia (Pengukir), was awarded as the Tokoh Adiguru Kraf of the wood in the field by the Perbadanan Kemajuan Kraftangan Malaysia. The analysis and findings were discussed in order to get more satisfactory results.

The timeline table of the houses were done to generate statistical graphs, bar charts and pie charts to get a typical percentage of statistical analysis review. The data were also analysed using Nvivo software application to get the relationship in order to develop the tree mapping and matrix coding.

\section{RESULTS AND FINDINGS}

All 50 houses of Limas Johor possessed interesting woodcarvings. Results and findings are as follows:

\section{Woodcarving Placements}

Based on the investigation, ten different placements have been identified of having the woodcarvings namely window railings or jerejak tingkap, window header panel or kepala tingkap, door header panel or kepala pintu, fascia board or papan meleh / cucur atap, barge board or papan layang, pinnacle or tunjuk langit, veranda railings or jerejak serambi, veranda door or pintu serambi, internal wall top panel or atas dinding dalaman and side panel of the floor slab or papan cantik. 
Hanita Yusof, Fawazul Khair Ibrahim, Raja Nafida Raja Shahminan

Heritage Identity Conservation of The Woodcarving Placement and Design Composition Typologies on Johor Malay Houses

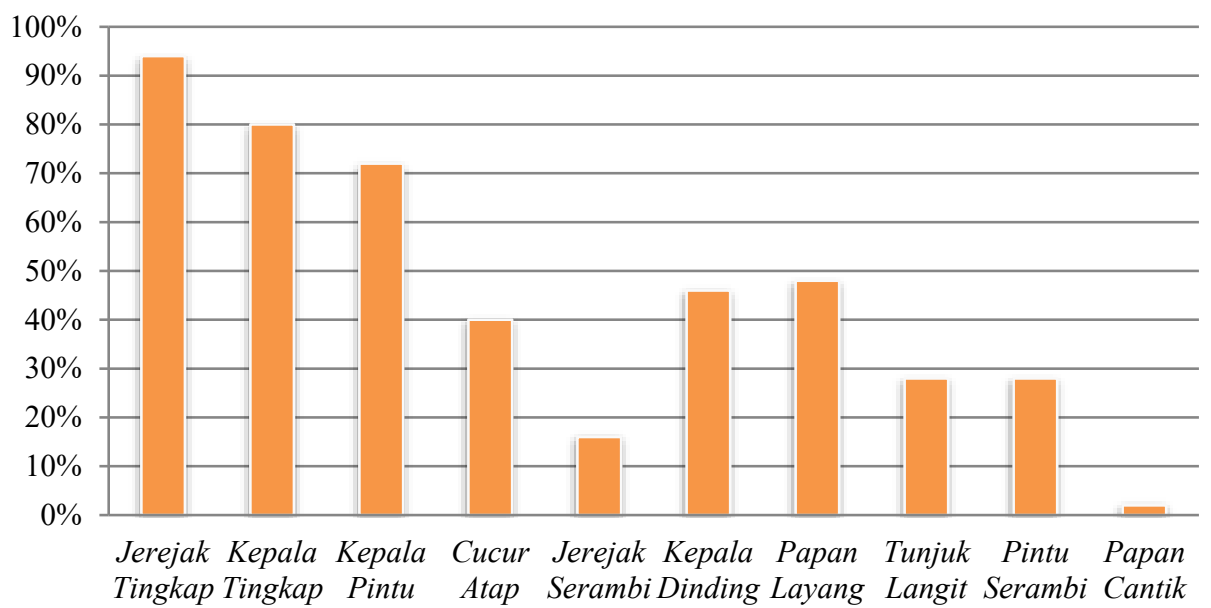

Figure 1: Result showing the percentage of woodcarving placements found in Limas Johor houses

Source: Hanita Yusof, 2018

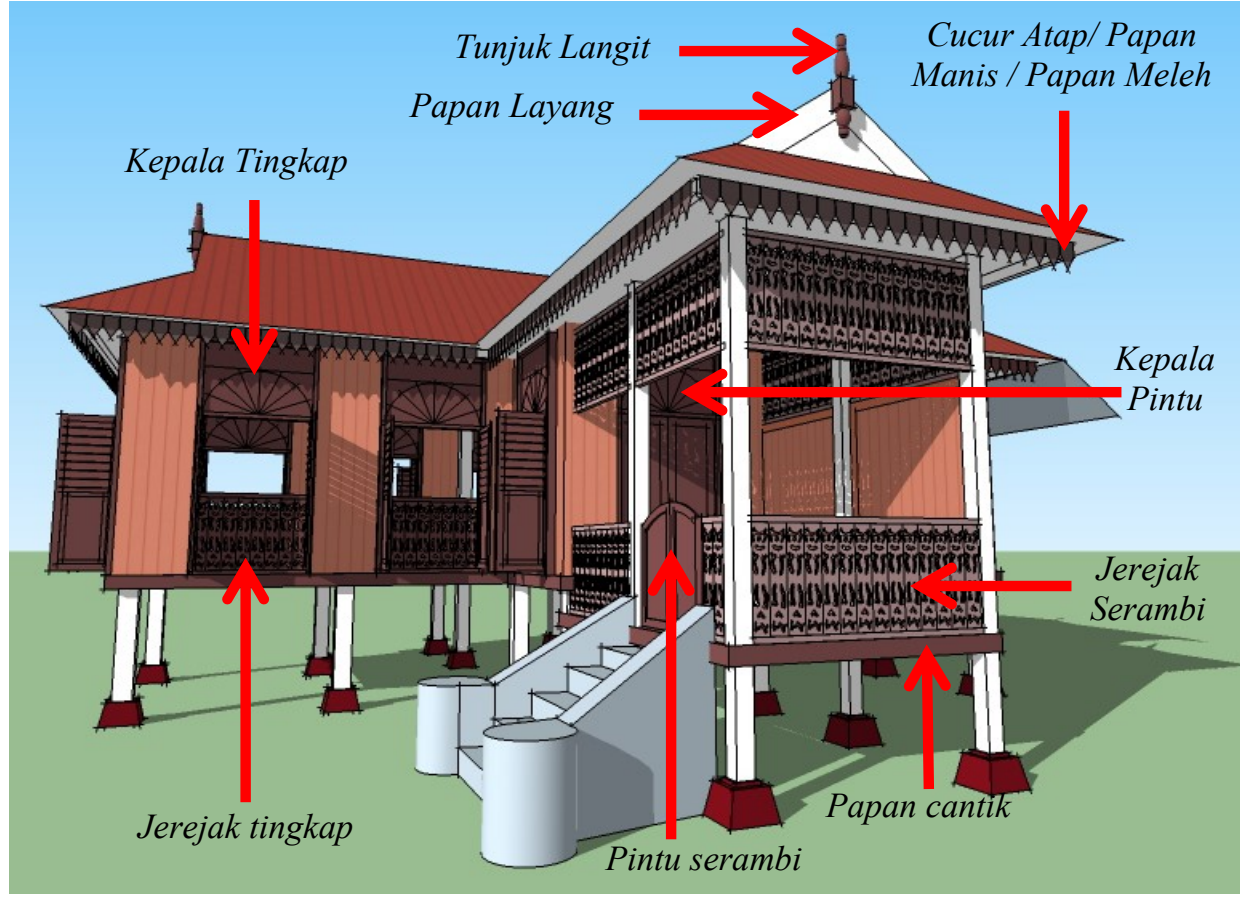

Figure 2: Eight out of ten woodcarving placements found in Limas Johor houses while woodcarving placements on the indoor are shown in figure below Source: Hanita Yusof, 2018 


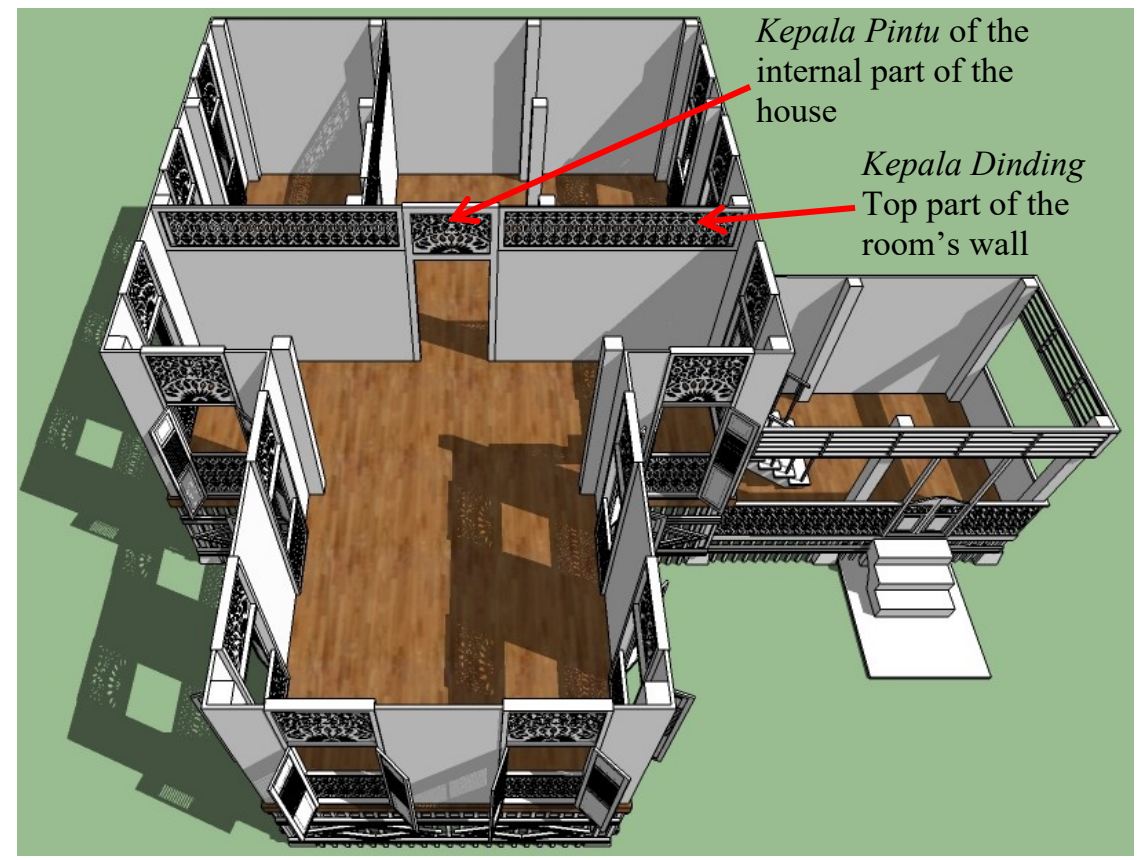

Figure 3: Two other woodcarving placements found inside Limas Johor houses which cannot be seen from the outside of the house

Source: Hanita Yusof, 2018

The result of the analysis of all 50 houses of Limas Johor revealed that nearly all houses have woodcarvings on their jerejak tingkap while the second highest percentage of placements that have woodcarvings are on their kepala tingkap. This result shows that the window is a significant element of woodcarvings placement compared to other placements in the house.

This finding revealed that the priority was given to jerejak tingkap to be decorated with woodcarving where it will enhance the beauty of the house from the front façade because of the position at the anjung is so dominant and noticeable since the anjung is protruded from the frontage. In addition to that, the floor level of the anjung is elevated more than 4 feets above the ground making the woodcarving at the jerejak tingkap at an appropriate point of sight where it is within the eye level viewing angle when the guest is standing outside the house. Apart from the aesthetical value occurs on the front façade of the house, it also contributes a significant function and beauty from the inside of the house. These woodcarvings provide magnificent effects as a result of the sunshine penetrating through the hollow part of the woodcarving, creating a shadow pattern on the floor. Moreover, this low placement is preferred because residents and guests are able to view the outdoor through the hollow part of the woodcarvings, aligned at 
Hanita Yusof, Fawazul Khair Ibrahim, Raja Nafida Raja Shahminan

Heritage Identity Conservation of The Woodcarving Placement and Design Composition Typologies on Johor Malay Houses

eye level, as they bersila (sitting on the floor) by the window. Besides, it functions well for the ventilation system compared to flat wood panel.
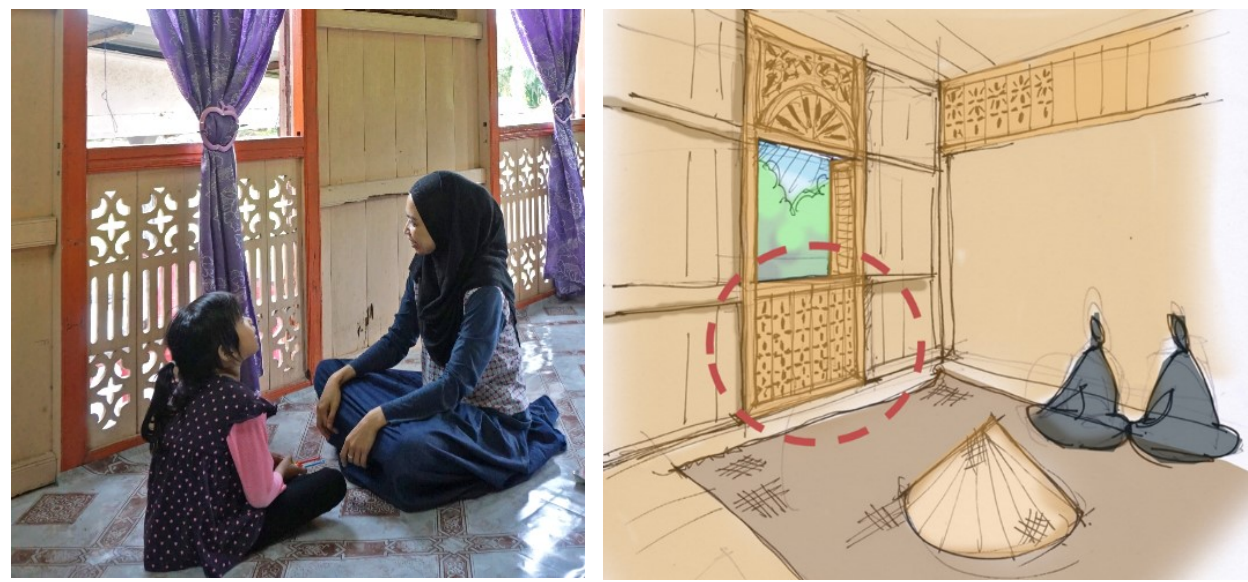

Figure 4: The placement of the woodcarving on jerejak tingkap in anjung is aligned within the occupants or guests' eye level viewing angle when bersila in the house that it also can function as ventilation as well Source: Hanita Yusof, 2018

\section{Design Composition Typologies}

The result of the analysis revealed 23 woodcarving design composition typologies that were found which 7 typologies for jerejak tingkap and 16 typologies for kepala tingkap placements. All 23 different typologies were drawn and coded. This research also contributed codings for the design composition typologies which are JT for jerejak tingkap, P for panels of the wood and KP for kepala tingkap for easier understanding and unique identification.
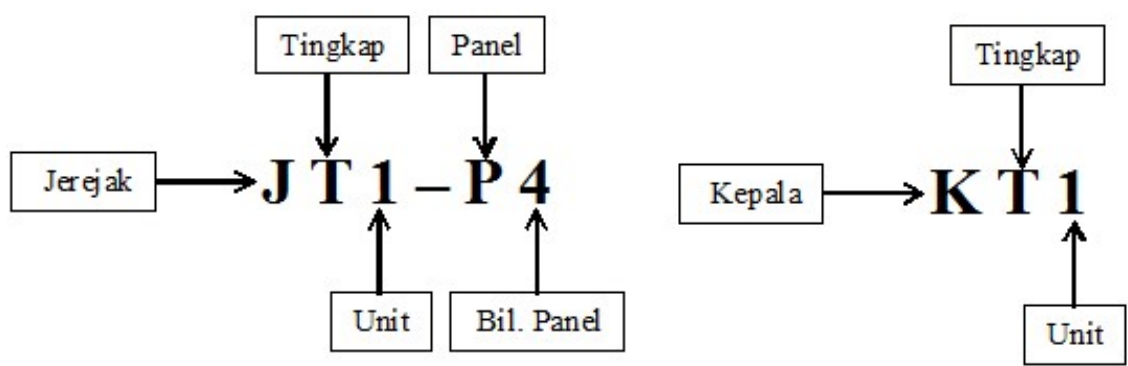

Figure 5: Figure above shows the coding for woodcarving design composition on jerejak tingkap and kepala tingkap Source: Hanita Yusof, 2018 
PLANNING MALAYSIA

Journal of the Malaysia Institute of Planners (2020)

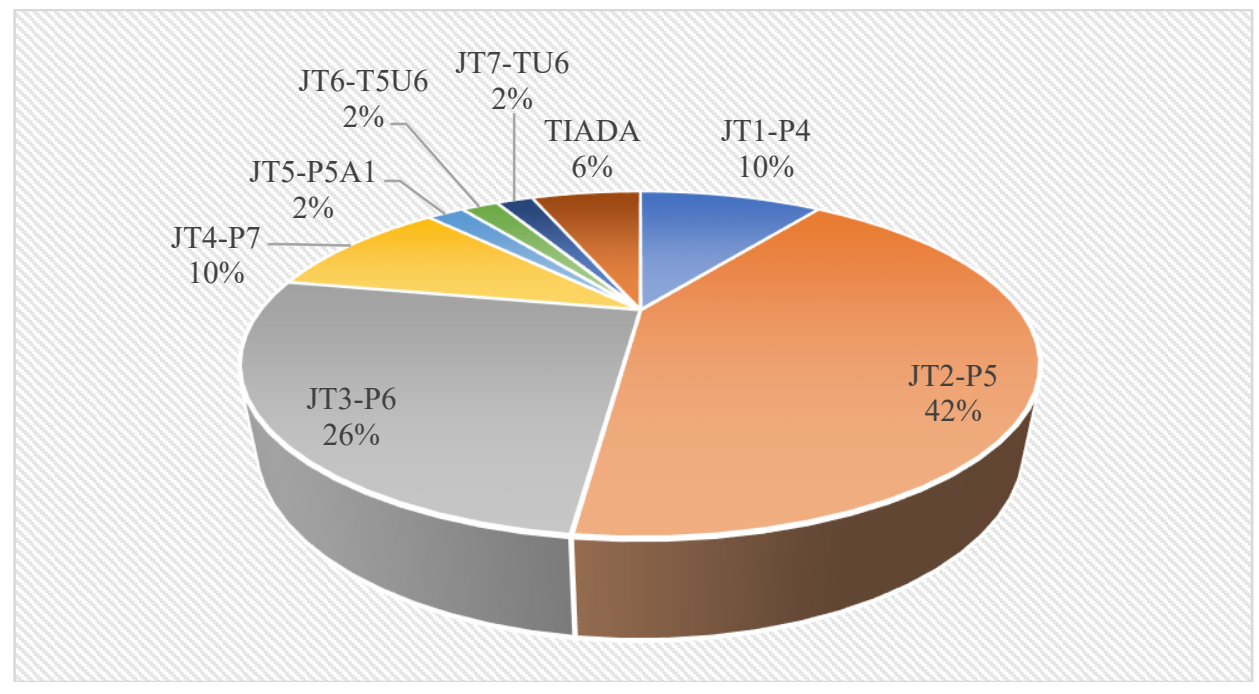

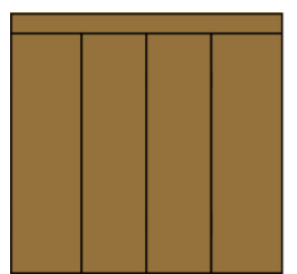

JT1-P4

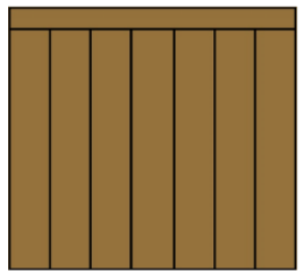

JT4-P7

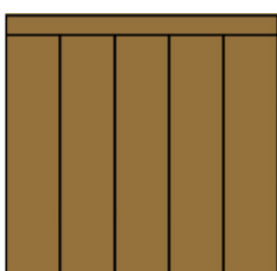

JT2-P5

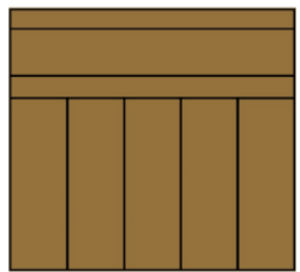

JT5-P5A1

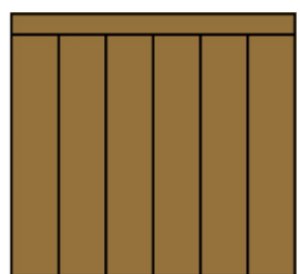

JT3-P6

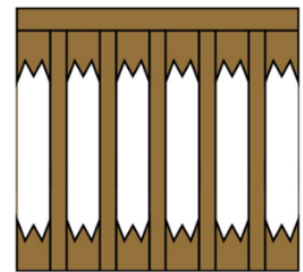

JT6-T5U6 $\square$ Ukiran kayu

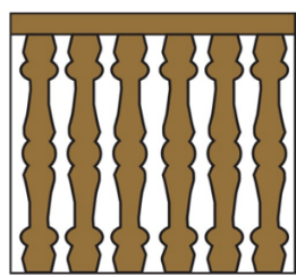

JT7-TU6

Figure 6: Seven typologies of the woodcarving design compositions found on the jerejak tingkap on Limas Johor houses and the percentage of each existence Source: Hanita Yusof, 2018 
Hanita Yusof, Fawazul Khair Ibrahim, Raja Nafida Raja Shahminan

Heritage Identity Conservation of The Woodcarving Placement and Design Composition Typologies on Johor Malay Houses
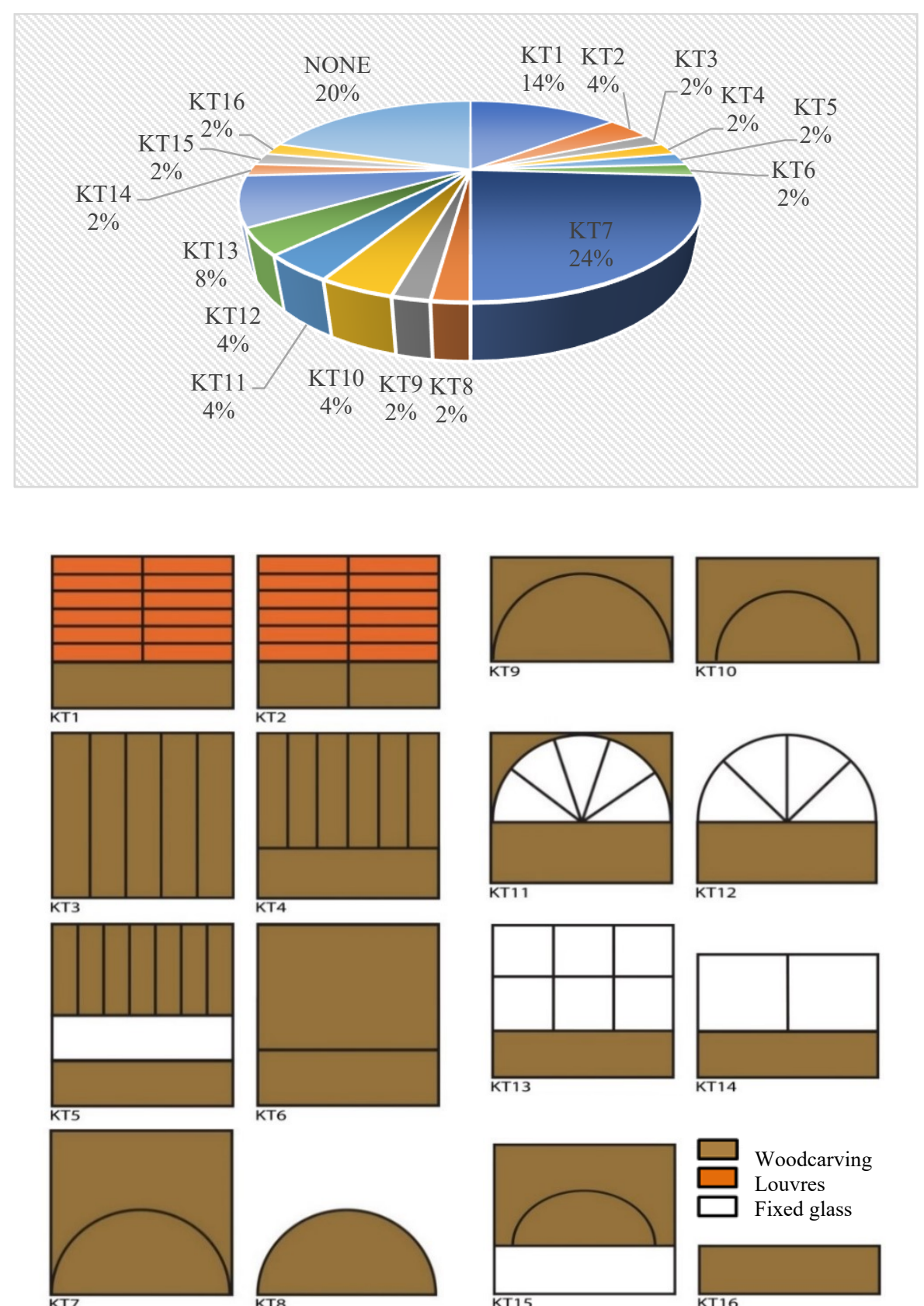

KT6
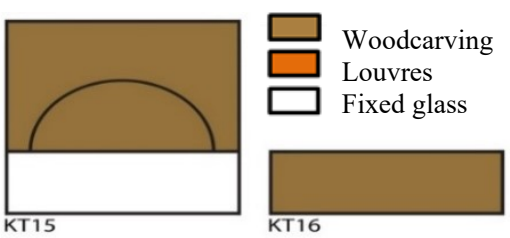

Figure 7: Sixteen typologies of the woodcarving design compositions found on the kepala tingkap on Limas Johor houses and the percentage of each existence Source: Hanita Yusof, 2018 
PLANNING MALAYSIA

Journal of the Malaysia Institute of Planners (2020)

\section{Identity}

As for the Limas Johor, the identity of the house is the limas roof. Apart from the roof, the anjung is one of the elements that contribute to the identity of Limas houses as it forms the limas roof. Since the anjung is protruded from the frontage and elevated above the ground at an appropriate point of sight where it is within the eye level viewing angle, the existence of woodcarving on the windows in the anjung is very noticeable and prominent. The placement of woodcarvings on the jerejak tingkap and kepala tingkap in the anjung is very dominant for the Limas Johor houses. The findings unite two placements of woodcarvings in the anjung under the typologies JT2-P5 + KT7 as an identity for design composition. This is because JT2-P5 has the highest percentage for jerejak tingkap and KT7 is the highest typology for kepala tingkap. The combination of both is very compatible and harmonious as the size of a jerejak tingkap is nearly similar to the size of the kepala tingkap of 33-36 inches. Thus, the findings of this research suggest that the placements of jerejak tingkap and kepala tingkap with the typology combination of JT2-P5+KT7 represents the identity of woodcarving design composition for Limas Johor houses.
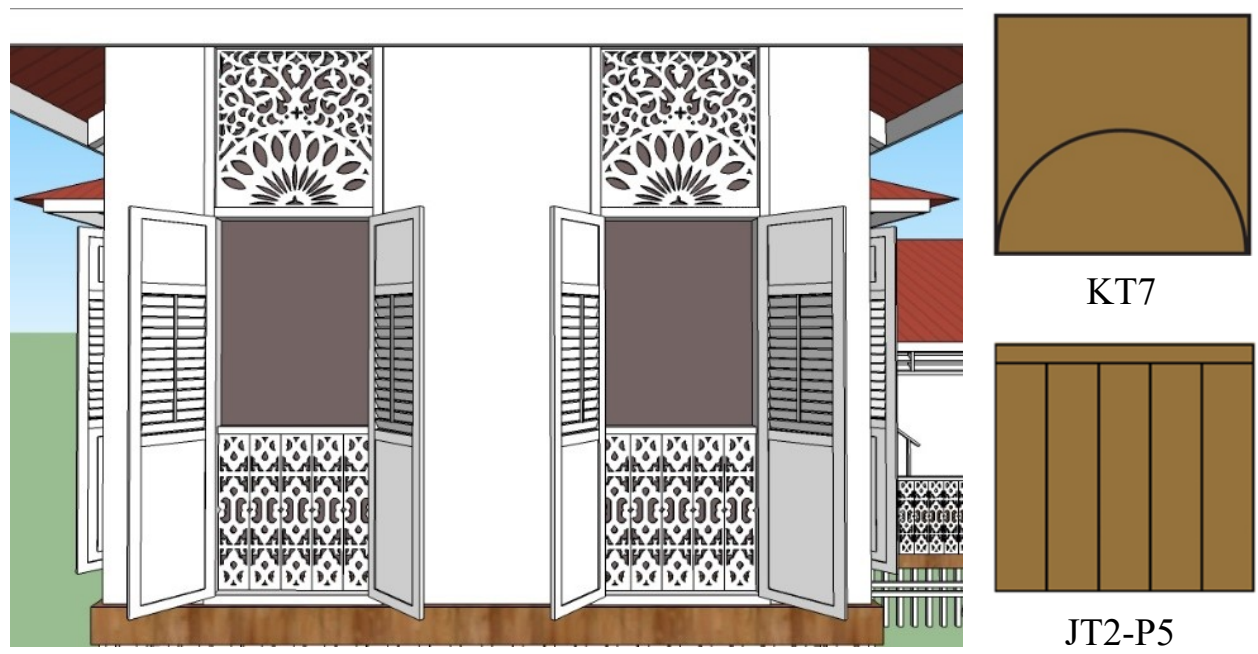

KT7

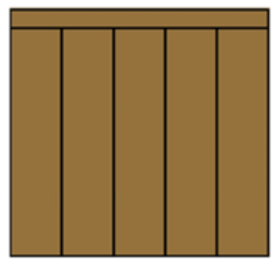

JT2-P5

Figure 8: The combination of two typologies JT2-P5 + KT7 of the woodcarving design compositions that dominates the Limas Johor houses Source: Hanita Yusof, 2018

This merging of two most dominant typologies is eligible to be proposed as an identity for the woodcarving design composition of Limas Johor houses. It is very momentous and significant to the Johor community due to its existence in the majority of the Limas Johor houses. 


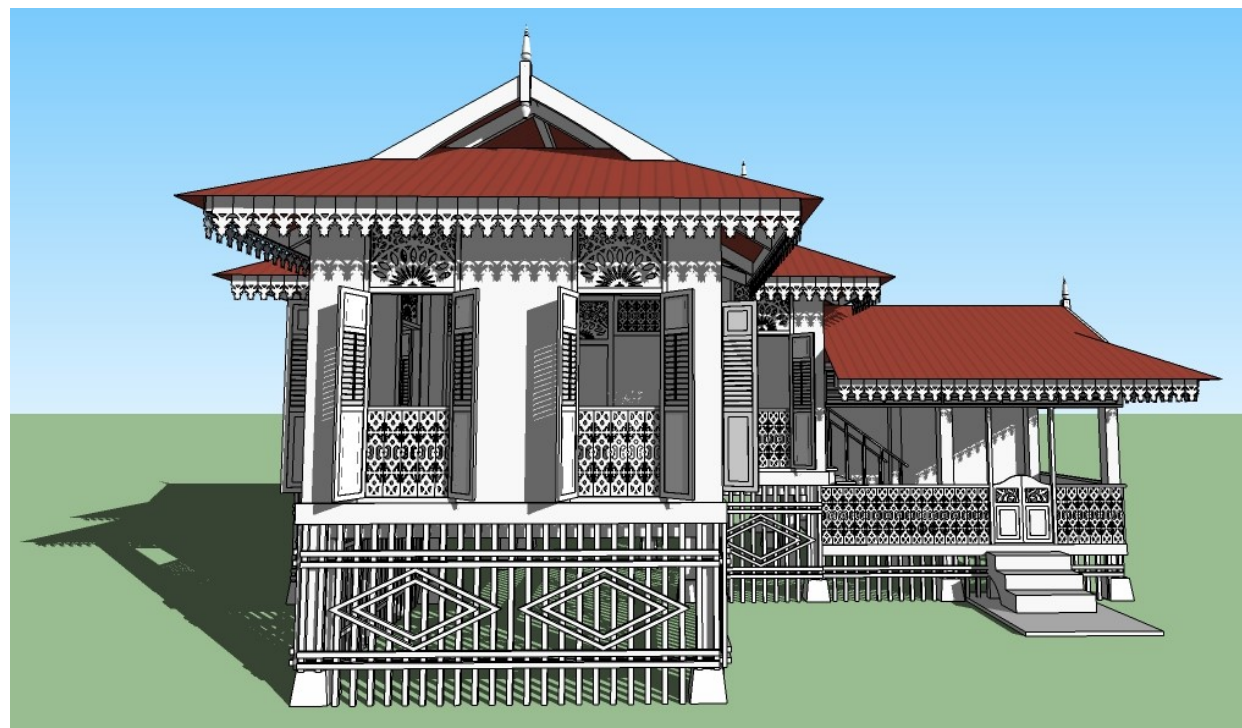

Figure 9: Front elevation showing the combination of typologies KT7 and JT2-P5 Source: Hanita Yusof, 2018

\section{CONCLUSIONS}

The findings revealed 10 woodcarving placements with the highest percentage of placements were found on the jerejak tingkap and kepala tingkap. 23 woodcarving design composition typologies were drawn and coded for both placements. The findings of this research suggest that the woodcarving placements of jerejak tingkap and kepala tingkap in the anjung with the typology combination of JT2-P5+KT7 represent the identity of woodcarving design composition for Limas Johor houses. These are really significant to the local architectural heritage of Limas Johor as it portrays the unity of the local people since 1820. All 10 placements and 23 compositions can be maintained as it can be used for the building of current Limas houses in Johor. It is important to promote the local identity and sustain the local belongings without imitating the identities of other countries. It is hoped that the findings will help to acknowledge Johor woodcarving unique identity, to be used for future generations. In addition, the findings could also provide valuable guides for woodcarvers to apply these typologies into their future works to sustain and cherish the Johor identity. Therefore, the local identity and the authentic value of the local heritage can be preserved.

\section{ACKNOWLEDGEMENT}

The authors wish to express their gratitude to the Centre of Research for the Study of Built Environment in the Malay World (KALAM) UTM. 
PLANNING MALAYSIA

Journal of the Malaysia Institute of Planners (2020)

\section{REFERENCES}

Abu Bakar Yatim (2015). Komunikasi Peribadi. Tanjung Gading, Muar, Johor.

Hanita Yusof (2018). Identiti Ukiran Kayu bagi Rumah Limas Johor. PhD Thesis, Universiti Teknologi Malaysia.

Gurupiah Mursib dan Syed Iskandar Syed Ahmad (2016). Significance of Local Involvement in Continuing Local Architectural Identity. MIT-UTM Malaysian Sustainable City Planning Program.

Jenkins, W. (2010). Keeping the Traditions of Malay Woodcarving Alive: The mission of Akademi Nik Rashiddin. In Zawiyah Baba. (Ed.) Warisan Seni Ukir Kayu Melayu. (pp 59-66). ATMA, Universiti Kebangsaan Malaysia.

Kamarul Afizi Kosman (2012). Peranan Masyarakat dalam Pembangunan Identiti Seni Bina Kebangsaan. In: Bengkel Garis Panduan Identiti Seni Bina Kebangsaan.

Mastor Surat (2012). Identiti Senibina Kebangsaan Melalui Pendekatan Senibina Warisan Alam Melayu. Dalam: Bengkel Garis Panduan Identiti Seni Bina Kebangsaan, 18-19 Disember 2012, The Royal Bintang Hotel.

Mohamad Tajuddin Mohamad Rasdi (2006). The Discontinued Traditions of Malay Wood Carvings in Modern and Post-Modern Architecture in Malaysia: Jurnal Alam Bina, Jilid 8, No.2, 2006. Universiti Teknologi Malaysia.

Mohamad Tajuddin Mohamad Rasdi \& Kamarul Afizi Kosman (2005). Identiti Seni Bina Malaysia: Pengajaran daripada Gerakan 'Art and Craft' di Britain. Jurnal Alam Bina. 7 (1). pp. 31-48. Universiti Teknologi Malaysia. ISSN 1511-1369.

Norhaiza Noordin (2009). Ukiran Kayu Warisan Melayu. Perbadanan Kemajuan Kraftangan Malaysia. Mantera Communication Sdn. Bhd.

Norhaiza Noordin (2017). Komunikasi Peribadi. Seri Menanti Resort, Negeri Sembilan.

Nor Hayati Hussain (2015). Thoughts on Malaysian Architecture Identity and Design Principles of Malayan Architects Co-Partnership; Tesis PhD, UTM.

Silah, Sumardianshah, Basaree, R. O., Isa, B. dan Redzuan, R. S. (2013). Tradition and Transformation: The Structure of Malay Woodcarving Motifs in Craft Education. Procedia - Social and Behavioral Sciences, 90 (InCULT 2012).

Yilmaz, M. \& Maz, M. (2006). Architectural Identity and Local Community. Ekistics, 73(436/441), 140-146. Retrieved from http://www.jstor.org/stable/43623731.

Zulkifli Hanafi (2007). Reka Bentuk Pola Hiasan dalam Bangunan Tradisional Melayu, Amber-Solara Publication.

Zulkifli Hanafi (2015). Seni Bina Melayu. In: Nuansa Ukiran Kayu Melayu. (pp. 17-29). Akademi Pengajian Melayu, Universiti Malaya.

Zumahiran Kamarudin \& Ismail Said (2010). Placement of Carved Components in Traditional Timber Houses of Kelantan and Terengganu. Warisan Seni Ukir Kayu Melayu, 129-142.

Zumahiran Kamarudin \& Ismail Said (2010). Carving Motifs in Timber Houses of Kelantan and Terengganu: Sustaining Malay Architecture Identity. Conference on Technology \& Sustainability in the Built Environment, 235-256.

Received: January 2020. Accepted: $1^{\text {st }}$ April 2020 